\title{
Patients with Parkinson's disease predict a lower incidence of colorectal cancer
}

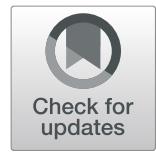

Hongsheng Fang ${ }^{1}$, Yunlan Du², Shuting Pan ${ }^{3}$, Ming Zhong ${ }^{1 *}$ and Jiayin Tang ${ }^{1 *}$

\begin{abstract}
Background: Recent theory on the "gut-brain axis" suggests a close relationship between the dysfunction of the gut and the disorders of the brain.

Methods: We performed a systemic literature search followed by a multi-step inclusion selection for all studies on the risk of Colorectal cancer (CRC) in Parkinson's disease (PD) patients using the following databases: PubMed, EMBASE and WOS. Relative risk (RR) and the 95\% confidence intervals (Cl) were calculated using either the randomeffects model or the fixed-effects meta-analysis model, based on the assessment of heterogeneity.

Results: Seventeen studies involving a total of 375,964 PD patients and 879,307 cancer patients were included. Independent meta-analyses for cohort studies and case-control studies showed that the overall pooled RR of the cohort studies was $0.78(0.66-0.91)$, and that of the case-control studies was $0.78(0.65-0.94)$, indicating that patients with PD have a significantly decreased risk for CRC. The significant lower risk is present in both the colon and the rectum subgroups classified by tumor location. Moreover, the risk for $C R C$ is significantly lower in America (RR= $0.58)$, Europe $(R R=0.82)$ and Asia $(R R=0.83)$ compared to the control population.
\end{abstract}

Conclusion: The occurrence of CRC was significantly lower in patients with diagnosis of PD.

Keywords: Colorectal cancer, Parkinson's disease, Risk, Meta-analysis

\section{Background}

Parkinson's disease (PD) is one of the most common neurodegenerative diseases characterized by motor dysfunction, such as resting tremor, rigidity, hypokinesia and postural instability [1], as well as non-motor symptoms including constipation and depression [2]. The etiology of PD remains unclear, both genetic and environmental factors contribute to it [3]. While the motor symptoms likely resulted from the loss of dopaminergic neurons in the substantia nigra [4], the nonmotor symptoms of PD are less well understood. The recent theory on the "gut-brain axis" postulates that the enteric microbiota may influence the cognitive behavior of the brain [5]. On the other hand, the characteristic

\footnotetext{
* Correspondence: ming.zhong@renji.com; jiayin.tang@shsmu.edu.cn 'Department of gastrointestinal surgery, Renji Hospital, School of Medicine, Shanghai Jiao Tong University, Shanghai, China

Full list of author information is available at the end of the article
}

protein aggregate in the PD brain, $\alpha$-synuclein, was also found to present in the enteric system [6, 7].

Colorectal cancer (CRC) is the third most common cancer and the second leading cause of cancer death worldwide [8]. CRC ranks the top five cancers in new diagnostic cancers and cancer-related death in China [9], making CRC one of the most serious health problems. CRC develops as the result of the accumulation of genetic and epigenetic alterations [10]. More recently, studies have also suggested that the alteration in the microbiota could generate local and systemic changes to influence oncogenesis [11].

These evidences from both the PD and CRC research fields have suggested a potential interaction between the pathogenic mechanisms of the brain and the gut. Previous epidemiology studies conducted in China showed inconsistent results, indicating the necessity of our research. The goal of the present study is to use the public

(c) The Author(s). 2021 Open Access This article is licensed under a Creative Commons Attribution 4.0 International License, which permits use, sharing, adaptation, distribution and reproduction in any medium or format, as long as you give appropriate credit to the original author(s) and the source, provide a link to the Creative Commons licence, and indicate if changes were made. The images or other third party material in this article are included in the article's Creative Commons licence, unless indicated otherwise in a credit line to the material. If material is not included in the article's Creative Commons licence and your intended use is not permitted by statutory regulation or exceeds the permitted use, you will need to obtain permission directly from the copyright holder. To view a copy of this licence, visit http://creativecommons.org/licenses/by/4.0/ The Creative Commons Public Domain Dedication waiver (http://creativecommons.org/publicdomain/zero/1.0/) applies to the data made available in this article, unless otherwise stated in a credit line to the data. 
database to explore the disease risk association between PD and CRC. In the recent 20 years, accumulating epidemiological studies have revealed that patients with PD may be associated with a lower risk of certain cancers [12-14], however, the association between PD and CRC remains controversial [15]. Therefore, we conducted this meta-analysis to provide a quantitative assessment of current epidemiological evidence on CRC in relation to $\mathrm{PD}$ and to explore the potential factors affecting the association between the two.

\section{Methods}

\section{Literature search}

Relevant studies from January 2000 to April 2020 were collected from the three major online databases including PubMed, Web of Science and EMBASE by two independent investigators (Hongsheng Fang and Jiayin Tang). We input PARKINSON DISEASE, PARKINSONISM, TUMOR, NEOPLASM, and CANCER as Medical Subject Heading (MeSH) terms and then connected through Boolean operators. We placed no restrictions on the region of residence or the age of the subjects, but we restricted the search to studies including human study participants. Moreover, the relevant reviews and references of articles were also manually screened to identify additional related studies that may supply relevant data. We conducted this meta-analysis according to the recommendations of the Preferred Reporting Items for Systematic Reviews and Meta-analysis (PRISMA) [16].

\section{Eligibility criteria}

Inclusion criteria were defined as follows: (1) Studies are either cohort or case-control studies about the CRC risk of PD patients (Secondary processing articles such as meta-analyses and reviews were excluded.); (2) An estimate of association [e.g. odds ratio (OR), relative risk $(\mathrm{RR})$, hazard ratio (HR) or standardized incidence ratio (SIR) and a 95\% confidence interval (CI)] can be collected from the study; (3) The distribution data could be obtained by contacting the author of a relevant report; (4) Studies contain the risk of CRC after the diagnosis of PD (Studies concerning the risk of CRC before the PD diagnosis were excluded.); (5) When duplicated studies were identified, only the most informative study was included.

\section{Quality assessment and data extraction}

The quality of the included articles was scored using the Newcastle-Ottawa scale (NOS) [17] by two investigators (Hongsheng Fang and Jiayin Tang) independently (Table S1), studies with NOS scores $>6$ were considered highquality studies. A third reviewer was recruited when disagreement rises. Data were extracted from eligible studies including author, publication year, type of study design (cohort or case-control), sample size, region, adjustment factors, RR and the $95 \% \mathrm{CI}$.

\section{Statistical analysis}

STATA 15.0 (Stata Corporation, College Station, TX, USA) was used to perform data analyses in this study. The pooled relative risk (RR) at the 95\% confidence interval $(95 \% \mathrm{CI})$ was assessed to evaluate the association between PD and CRC. The RR and the 95\% CI was calculated using the "inverse variance" method; and the statistical heterogeneity was evaluated using the $\mathrm{I}^{2}$ statistics [18]. The fixed-effects meta-analysis model was used when $\mathrm{I}^{2}$ is less than $50 \%$ and the random-effects metaanalysis model was used when $\mathrm{I}^{2}$ is higher than $50 \%$ [19]. The RR was used instead of other related measures (such as OR、HR or SIR) because the incidence of PD and CRC are both rare. The effect of publication bias was evaluated by the Begg's and Egger's tests [20]. Statistical significance was determined at $P$ value less than 0.05 .

\section{Results \\ Eligible studies}

The systemic search result and the subsequent eligibility selection workflow is shown in Fig. 1. Our initial search identified a total of 586 potential match in the database. After exclusion of 60 duplicate studies, 526 studies remained. We next excluded 490 studies that fail to provide information on the association between $\mathrm{PD}$ and CRC, leaving 36 full-text articles. After a careful review of the remaining 36 studies, 19 studies did not meet our 5 inclusion criteria above (10 studies with no aim outcome or complete results, 5 studies are not original investigation such as review; 4 studies were performed on the same population). Finally, we collected 17 eligible studies for further analyses. All 17 studies were published between January 2000 and April 2020, which included 13 cohort studies (12 retrospective studies and 1 prospective study) and 4 case-control studies. To classify the 17 studies by geographical region, 7 studies were based on the European population [21-27], 6 studies are performed in American population [28-33], while 4 studies are conducted in Asian population [14, 15, 34, 35]. The baseline characteristics of all included studies are shown in Table 1.

\section{Overall association between CRC and PD}

The pooled RRs of the overall CRC risk in PD patients was 0.78 (95\% CI: $0.66-0.91, p<0.001, \mathrm{I}^{2}=90.4 \%=$ in the cohort studies (Fig. 2) and 0.78 (95\%CI: 0.65-0.94, $p<$ $0.001, \mathrm{I}^{2}=0 \%=$ in the case-control studies (Fig. 3), indicating that the PD patients are associated with an overall decreased risk of CRC compared with the control population. However, we observed that the $\mathrm{I}^{2}$ is more than 


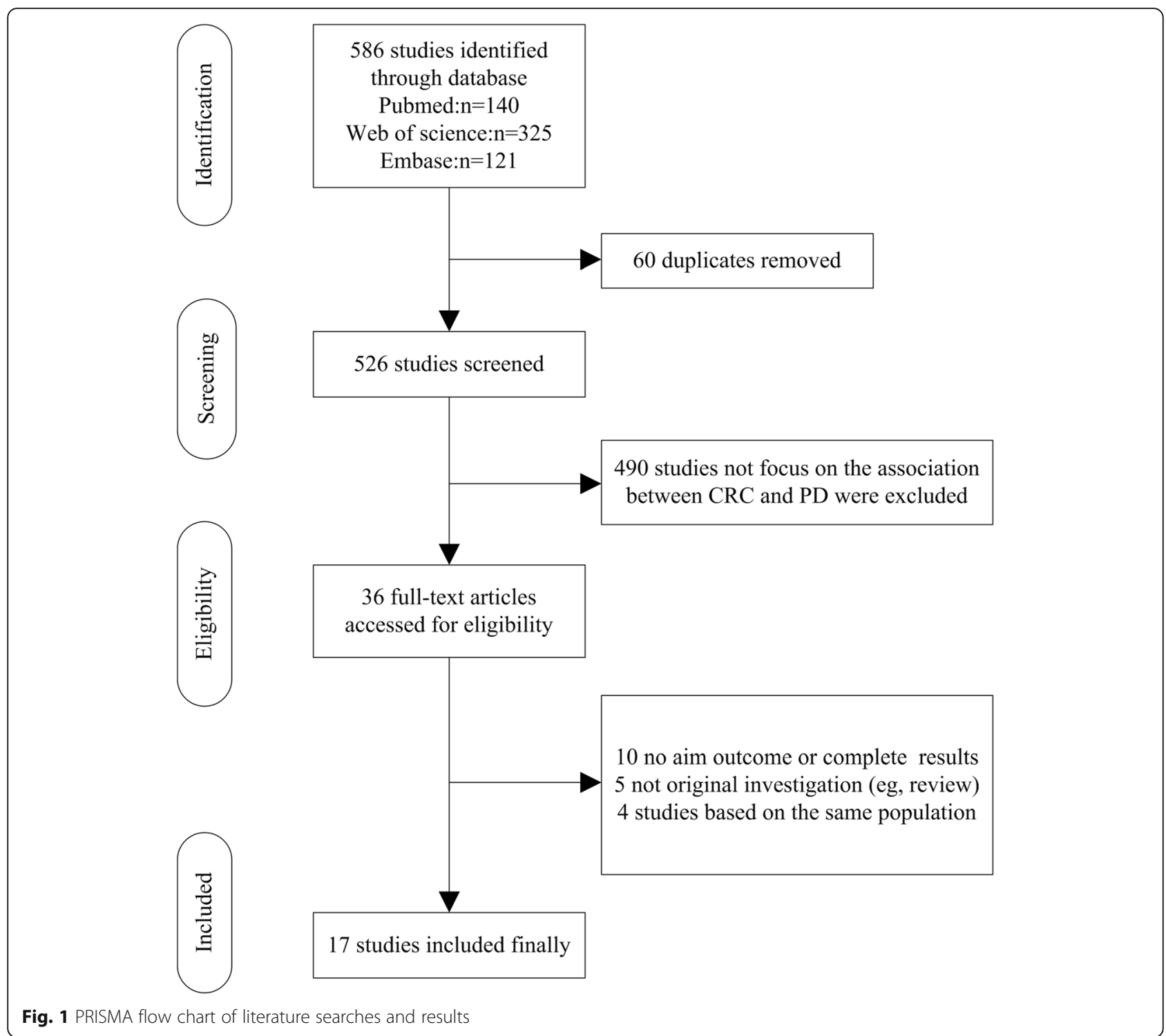

$50 \%$ in the cohort studies, suggesting high heterogeneity. To understand the source of this unusually high heterogeneity, we examined all studies and found one with the highest OR of 1.47 [15]. By excluding this particular study, we reduced the heterogeneity by nearly $18.3 \%$ (heterogeneity $\mathrm{I}^{2}=72.1 \%$ ).

\section{Results of subgroup analysis}

We carried out a series of subgroup analyses based on the tumor location and the region of population, subgroups are selected only from the cohort studies (Table 2). We found that the inverse risk association between PD and CRC persisted even after stratifying the studies by the above factors. Subset analyses of the two study designs showed a consistently decreased cancer risk, with a combined $\mathrm{RR}$ of $0.80(p<0.001=$ for cohort studies and $0.76(p<0.001)$ for case-control studies. In analyses stratified by tumor location, the combined risk for colon tumor with PD is 0.68 (95\% CI, 0.55-0.83, $p<$ 0.001 ) (Fig. S1), and that for rectum tumor with $\mathrm{PD}$ is 0.89 (95\% CI, 0.83-0.95, $p<0.001$ ) (Fig. S2). To segregate the data by geographical region (Table 2), the average OR was the lowest in data from the American population $(\mathrm{OR}=0.58 ; 95 \% \mathrm{CI}, 0.46-0.74, p<0.001)$ (Fig. S3), followed by data from the European population (OR = 0.82; 95\% CI, 0.74-0.9, $p<0.001$ ) (Fig. S4), in the data obtained from Asia, the OR is 0.83 with $95 \%$ CI (0.51-1.34, $p=0.442$ ) (Fig. S5). PD patients in these areas showed significantly lower CRC risk compared to the control population. It is worth noting that the heterogeneity $\left(\mathrm{I}^{2}\right)$ in the Asia group would reduce from 97 to $0 \%$ if excluding the study with OR of 1.47 . 
Table 1 Baseline characteristics of all included studies in the meta-analysis

\begin{tabular}{|c|c|c|c|c|c|c|c|c|}
\hline Author & Year & Country & $\begin{array}{l}\text { Study } \\
\text { design }\end{array}$ & $\begin{array}{l}\mathrm{N} \\
\text { (case) }\end{array}$ & $\begin{array}{l}\mathrm{N} \\
\text { (control) }\end{array}$ & subsite & SQ & adjustment \\
\hline Guttman [28] & 2003 & Canada & $\begin{array}{l}\text { retrospective } \\
\text { cohort }\end{array}$ & $\begin{array}{l}15,304 \\
\text { PD }\end{array}$ & 30,608 & colon & 6 & age, sex \\
\hline OLsen [21] & 2005 & Denmark & $\begin{array}{l}\text { retrospective } \\
\text { cohort }\end{array}$ & $\begin{array}{l}14,088 \\
\mathrm{PD}\end{array}$ & NR & $\begin{array}{l}\text { colon } \\
\text { trectum }\end{array}$ & 6 & age, sex \\
\hline Powers [29] & 2005 & USA & Case-control & 352 PD & 484 & colorectal & 6 & age, ethnicity, education, smoking \\
\hline Driver [30] & 2007 & USA & $\begin{array}{l}\text { prospective } \\
\text { cohort }\end{array}$ & 487 PD & 487 & colorectal & 6 & age \\
\hline Fois [22] & 2009 & UK & $\begin{array}{l}\text { retrospective } \\
\text { cohort }\end{array}$ & $\begin{array}{l}4355 \\
\mathrm{PD}\end{array}$ & 574,860 & $\begin{array}{l}\text { colon } \\
\text { rectum }\end{array}$ & 7 & age, sex, year of first hospital admission, region \\
\hline Becker [23] & 2010 & UK & $\begin{array}{l}\text { retrospective } \\
\text { cohort }\end{array}$ & $\begin{array}{l}2993 \\
\text { PD }\end{array}$ & 3003 & colorectal & 6 & age, sex, smoking, body mass index, \\
\hline Lo [31] & 2010 & USA & $\begin{array}{l}\text { retrospective } \\
\text { cohort }\end{array}$ & 692 PD & 761 & colorectal & 7 & $\begin{array}{l}\text { age, sex, ethnicity, education (years), annual income, smoking, } \\
\text { alcohol consumption, body mass index }\end{array}$ \\
\hline Sun [14] & 2011 & $\begin{array}{l}\text { Taiwan, } \\
\text { China }\end{array}$ & $\begin{array}{l}\text { retrospective } \\
\text { cohort }\end{array}$ & $\begin{array}{l}4957 \\
\text { PD }\end{array}$ & 19,828 & colorectal & 6 & age, sex \\
\hline $\begin{array}{l}\text { Rugbjerg } \\
{[24]}\end{array}$ & 2012 & Denmark & $\begin{array}{l}\text { retrospective } \\
\text { cohort }\end{array}$ & $\begin{array}{l}20,343 \\
P D\end{array}$ & 32,360 & colorectal & 7 & age, sex, calendar year \\
\hline Ong [25] & 2014 & UK & $\begin{array}{l}\text { retrospective } \\
\text { cohort }\end{array}$ & $\begin{array}{l}219,194 \\
\text { PD }\end{array}$ & $9,015,614$ & $\begin{array}{l}\text { colon } \\
\text { trectum }\end{array}$ & 8 & age, sex, calendar year, region of residence, quintile of patients \\
\hline $\begin{array}{l}\text { Wirdefeldt } \\
{[26]}\end{array}$ & 2014 & Sweden & $\begin{array}{l}\text { retrospective } \\
\text { cohort }\end{array}$ & $\begin{array}{l}11,786 \\
P D\end{array}$ & 58,930 & $\begin{array}{l}\text { colon } \\
\text { trectum }\end{array}$ & 7 & sex, birth year \\
\hline Lin [15] & 2015 & $\begin{array}{l}\text { Taiwan, } \\
\text { China }\end{array}$ & $\begin{array}{l}\text { retrospective } \\
\text { cohort }\end{array}$ & $\begin{array}{l}62,023 \\
P D\end{array}$ & 124,046 & colorectal & 8 & age, sex \\
\hline Peretz [34] & 2016 & Israel & $\begin{array}{l}\text { retrospective } \\
\text { cohort }\end{array}$ & $\begin{array}{l}7125 \\
\mathrm{PD}\end{array}$ & NR & $\begin{array}{l}\text { colon } \\
\text { +rectum }\end{array}$ & 7 & age, sex, chronological year \\
\hline Boursi [27] & 2016 & UK & Case-control & $\begin{array}{l}22,093 \\
\text { cancer }\end{array}$ & 85,833 & colorectal & 6 & $\begin{array}{l}\text { Obesity, diabetes, smoking, alcohol consumption, NSAIDs use, } \\
\text { hormone replacement therapy, screening colonoscopy }\end{array}$ \\
\hline $\begin{array}{l}\text { Freedman }(1) \\
{[33]}\end{array}$ & 2016 & USA & Case-control & $\begin{array}{l}836,947 \\
\text { cancer }\end{array}$ & 142,869 & $\begin{array}{l}\text { colon } \\
\text { +rectum }\end{array}$ & 5 & age, sex, selection year \\
\hline $\begin{array}{l}\text { Freedman(2) } \\
{[32]}\end{array}$ & 2016 & Asia & Case-control & $\begin{array}{l}20,267 \\
\text { cancer }\end{array}$ & 5558 & colon & 5 & age, sex, selection year \\
\hline Park [35] & 2019 & Korea & $\begin{array}{l}\text { retrospective } \\
\text { cohort }\end{array}$ & $\begin{array}{l}52,009 \\
P D\end{array}$ & 260,045 & colorectal & 8 & age, sex, hypertension, DM, hyperlipidemia \\
\hline
\end{tabular}

Notes: Study quality was judged based on the Newcastle-Ottawa Scale,

Abbreviations: $N$ number of studies, NR not reported, SQ score of study quality, RR relative risk, Cl confidence intervals

\section{Sensitivity analysis}

In our meta-analysis, sensitivity analysis was conducted to assess the stability of the results. The persistent inverse association between $\mathrm{PD}$ and CRC risk did not change in the sensitivity analysis, which was conducted by omitting one study per iteration. (Fig. S6).

\section{Publication bias analysis}

We used Begg's and Egger's tests to evaluate publication bias in this meta-analysis. The funnel plot was almost symmetric (Fig. S7), the Egger test for publication bias $(p=0.319)$ showed no significant evidence for bias in the data, Begg's test $(p=0.951)$ was also not strongly suggestive of publication bias, thus confirming the absence of obvious publication bias in these studies (Fig. S8).

\section{Discussion}

$\mathrm{PD}$ is an age-related neurodegenerative disorder commonly diagnosed at the age of 60 and above. CRC is increasingly common in people over the age of 60. PD and CRC are totally different illnesses and are thought to have different pathogenic mechanisms. For example, PD is characterized by the death of dopaminergic neurons in the substantia nigra, while CRC derives from the inappropriate cell proliferation with a selective growth advantage. Growing evidence have suggested that patients with PD may have a substantially lower incidence of cancer, but the risk association with CRC is less clear.

Prior to our study, there was only one meta-analysis examining the association between PD and CRC. Unfortunately, there were several caveats and weaknesses associated with that study: (1) It was unclear if the results represented the risk of cancer influenced by $\mathrm{PD}$, or vice 


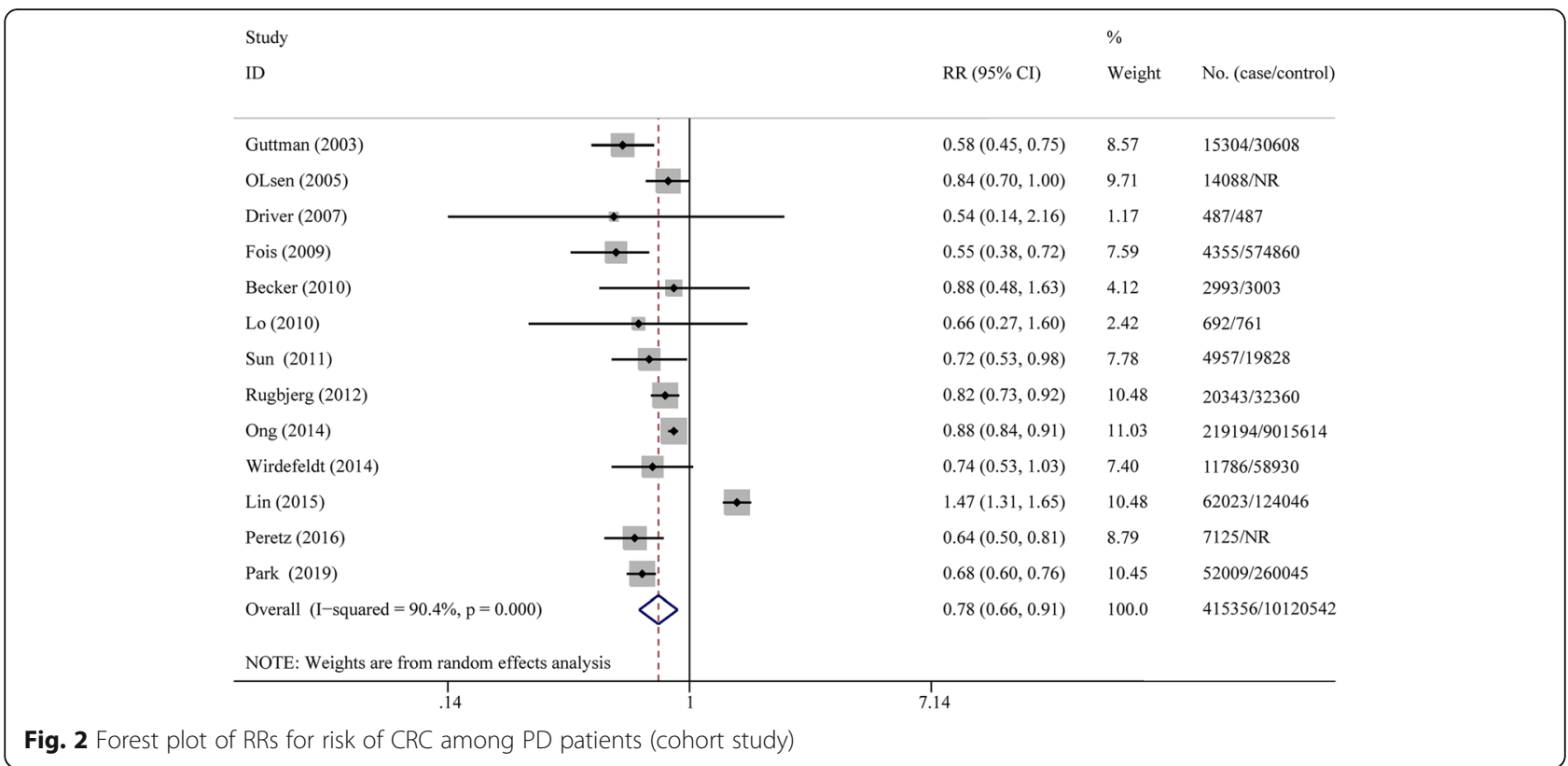

versa; (2) The data collected in that study was incomplete; (3) It is methodologically wrong to mix the results from the cohort studies and the case-control studies due to the different design of the two studies.

Our study has overcome the aforementioned weaknesses in the previous work and examined specifically the risk of CRC in patients with diagnosis of PD. We analyzed 17 studies involving 375,964 PD patients and 879,307 cancer patients. The pooled results for all populations indicated that PD patients have a decreased risk of CRC in Western population. Subgroup analysis showed that the significant inverse relationship between $\mathrm{PD}$ and risk of CRC is not affected by differences in types of study design, tumor location, or different regions of the Western population.
The inverse association between PD and CRC in the Western population is statistically significant in our study. However, the association in the Asian population remains obscure. We found contradictory conclusions in published studies. In our meta-analysis, we identified a modest lower risk of CRC in patients with $\mathrm{PD}(\mathrm{RR}=$ 0.83 ) with a high level of heterogeneity $\left(\mathrm{I}^{2}=97 \%\right)$ and the significance is not as clear as data from the American and European groups $(P=0.442)$. We think the reason could be due to the wide variability of the Asian data. Some large-scale studies on the Asian population are unfortunately not completed like the similar studies for the Western population. For the two studies that are completed in Taiwan, China, the results are opposite. The RR of the study completed by Sun [14] in 2011 is

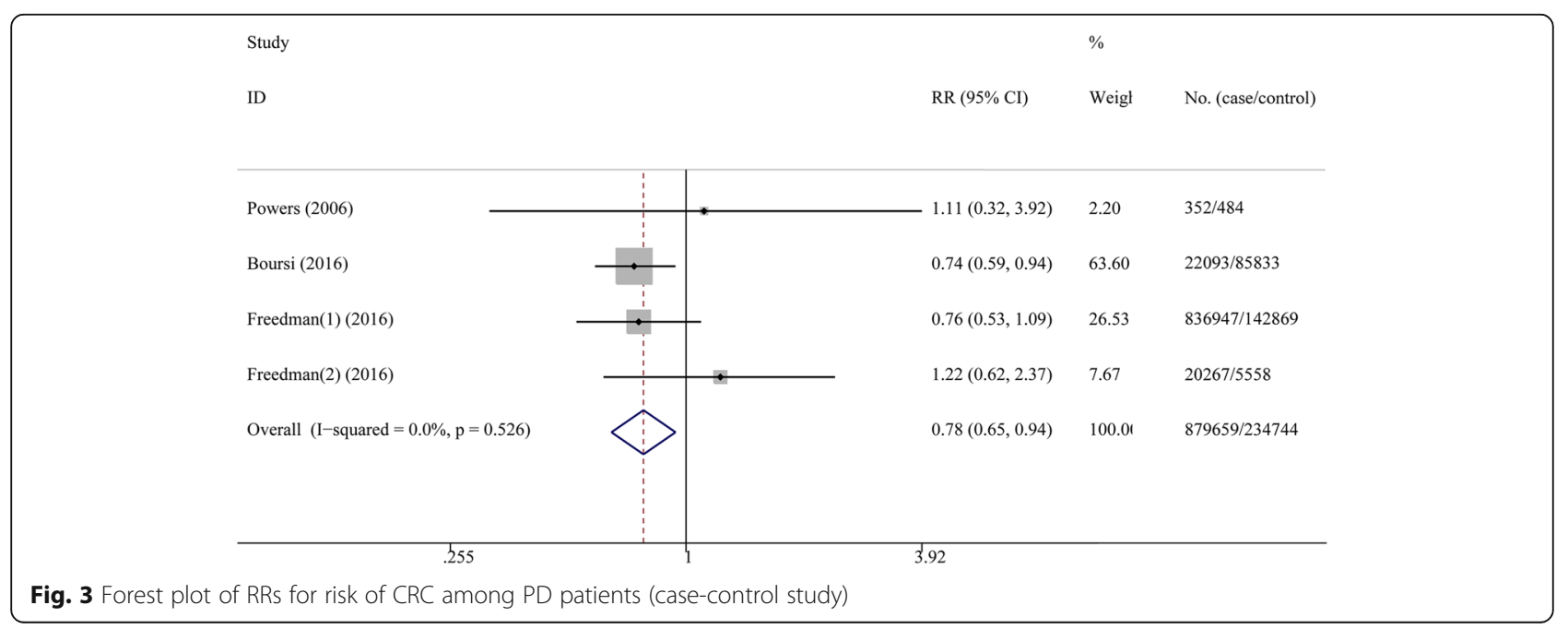


Table 2 Subgroup analysis

\begin{tabular}{|c|c|c|c|c|c|c|}
\hline \multirow[t]{2}{*}{ Categories } & \multirow[t]{2}{*}{$N$} & \multirow{2}{*}{$\begin{array}{l}\text { Pooled } \\
\text { RR }\end{array}$} & \multirow[t]{2}{*}{$95 \% \mathrm{Cl}$} & \multirow[t]{2}{*}{$P$ value } & \multicolumn{2}{|c|}{ Heterogeneity } \\
\hline & & & & & $\overline{1^{2}}$ & $P^{\prime}$ \\
\hline \multicolumn{7}{|l|}{ Study design } \\
\hline Cohort & 13 & 0.78 & $0.66-0.91$ & $<0.001$ & $90.4 \%$ & $<0.001$ \\
\hline Case-control & 4 & 0.78 & $0.65-0.94$ & $<0.001$ & $0 \%$ & 0.526 \\
\hline \multicolumn{7}{|l|}{ Cancer location } \\
\hline Colon & 6 & 0.68 & $0.55-0.83$ & $<0.001$ & $86.2 \%$ & $<0.001$ \\
\hline Rectum & 5 & 0.89 & $0.83-0.95$ & $<0.001$ & 0 & 0.887 \\
\hline \multicolumn{7}{|c|}{ Geographical region } \\
\hline America & 3 & 0.58 & $0.46-0.74$ & $<0.001$ & 0 & 0.957 \\
\hline Europe & 6 & 0.82 & $0.74-0.90$ & $<0.001$ & $51 \%$ & 0.070 \\
\hline Asia & 4 & 0.83 & $0.51-1.34$ & 0.442 & $97 \%$ & $<0.001$ \\
\hline
\end{tabular}

0.72 (95\% CI 0.53-0.99). The study consisted of 4957 newly diagnosed PD cases in the cohort and 19,828 nonPD controls during the period of 2000-2005 from the Taiwan National Health Insurance (NHI) Research Database (NHIRD), a nationwide population-based database containing more than 24 million subjects covering 99\% of the entire population in Taiwan, China. The other study that completed by Lin [15] in Taiwan, China in 2015 is the main source of heterogeneity, the pooled OR of this study is 1.47 (95\% CI, 1.31-1.65), and the cohort study included 133,322 individuals with PD newly diagnosed between 2004 and 2010, also from the NHI database. Freedman [32] et al. adjusted for a surrogate for surveillance (number of physician visits) and found that the odds of cancer in the total population after PD was reduced, suggesting that the medical surveillance contributed to the risks.

The key question that our study begs is the potential mechanism that may account for the negative association between PD and CRC. The level of melatonin [36], dopamine [37], smoking [38] and diabetes [39] have all been proposed to account for such mechanisms. More importantly, patients with PD often have microflora alterations in their feces and colonic mucosa, which may lead to non-motor symptoms such as constipation [40]. Interestingly, recent studies have also pointed to the role of microbiome and their secretion in inducing local and systemic effects on cancer onset and progression [11]. Thus, a detailed analysis on the types of microbiota may provide clues to a negative association between PD and CRC. At the molecular level, dysfunction of the ubiquitin-proteasome system (UPS) leads to an accumulation of intracellular proteins and formation of Lewy bodies containing $\alpha$-synuclein, which is the characteristic pathological feature of PD $[41,42]$. In contrast, the function of UPS is usually up-regulated in CRC [43].
Whether the UPS stands at the crossroads of dysregulation for PD and CRC awaits further studies. Moreover, studies have shown that the PI3K /AKT/mTOR pathways are hyperactive in patients with CRC [44] while the activation of the PI3K/AKT/mTOR pathway may promote the survival of dopaminergic neurons by inhibiting apoptosis, thus preventing PD [45].

Our meta-analysis has provided a most up-to-date picture for the CRC risk in PD patients. As CRC patients often exhibit a much more aggressive disease course than the PD patients, the risk of PD in CRC patients is hard to calculate. Our study, thus, made a strong conclusion for the inverse CRC risk from the Western PD population, while that for the Asian population remains obscure due to large heterogeneity and a small number (4) of available datasets. It is worth noting that publication bias and other forms of bias may still exist, and a more detailed subgroup analysis is incomplete due to the insufficient data from the primary articles. Nonetheless, our study has several strengths, including its comprehensive literature search for the latest data, large number of cases, careful assessment of the quality of evidence, which altogether made the results more reliable compared to earlier studies.

\section{Conclusion}

In conclusion, our research suggests that patients with PD predict a lower risk of CRC. Further studies are warranted to explore the underlying mechanisms of this correlation and to prevention and treatment of both diseases.

\section{Abbreviations}

RR: Relative risks; OR: Odds ratio; HR: Hazard ratio; $\mathrm{Cl}$ : Confidence intervals; NR: not reported; SQ: score of study quality; $\mathrm{N}$ : number of studies; $\mathrm{P}^{\prime}: p$ value of $\mathrm{I}^{2}$ statistics for heterogeneity; PRISMA: Preferred Reporting items for System Review and Meta-analysis; NOS: Newcastle-Ottawa Scale

\section{Supplementary Information}

The online version contains supplementary material available at https://doi. org/10.1186/s12877-021-02497-z.

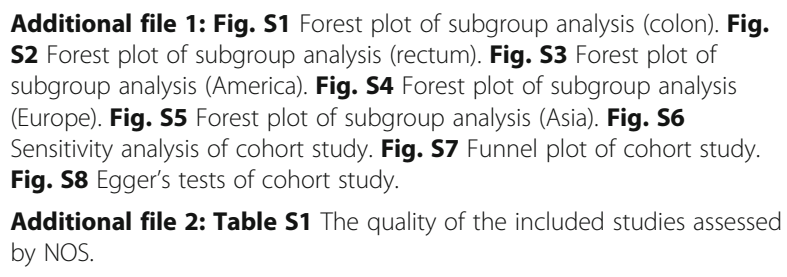

Additional file 2: Table S1 The quality of the included studies assessed by NOS.

\section{Acknowledgements}

We are especially grateful to Hao Wang, who helped to revise the methodology. We thank our colleagues for their critical comments and kind help.

\section{Authors' contributions}

Conceptualization: J.T. and Y.D. Methodology: H.F. and J.T. Formal analysis: H.F. Investigation: H.F. Data curation: H.F. Writing-original draft preparation: 
H.F. and J.T. Writing-review and editing: H.F., J.T. and Y.D. Supervision: J.T. and M.Z. Project administration: J.T. and M.Z. Funding acquisition: M.Z. All authors have read and agreed to the published version of the manuscript.

\section{Funding}

This work was supported by grants from the National Natural Science Foundation of China (82072619, 81672347, 81873555); Shanghai Municipal Commission of science and technology (19411966200). The funder had no role in study design, data collection and analysis, decision to publish, or preparation of the manuscript.

\section{Availability of data and materials}

All data generated or analyzed during this study are included in this published article and its supplementary information files.

\section{Declarations}

\section{Ethics approval and consent to participate}

Not applicable.

\section{Consent for publication}

Not applicable.

\section{Competing interests}

The authors declare no conflict of interest.

\section{Author details}

${ }^{1}$ Department of gastrointestinal surgery, Renji Hospital, School of Medicine, Shanghai Jiao Tong University, Shanghai, China. ²Department of Neurology, Renji Hospital, School of Medicine, Shanghai Jiao Tong University, Shanghai, China. ${ }^{3}$ Clinical Center for Investigation, Renji Hospital, School of Medicine, Shanghai Jiao Tong University, Shanghai, China.

Received: 12 February 2021 Accepted: 22 September 2021 Published online: 18 October 2021

\section{References}

1. de Lau LM, Breteler MM. Epidemiology of Parkinson's disease. Lancet Neurol. 2006;5(6):525-35. https://doi.org/10.1016/S1474-4422(06)70471-9.

2. Schapira AHV, Chaudhuri KR, Jenner P. Non-motor features of Parkinson disease. Nat Rev Neurosci. 2017;18(7):435-50. https://doi.org/10.1038/nrn.201 7.62.

3. Ascherio A, Schwarzschild MA. The epidemiology of Parkinson's disease: risk factors and prevention. Lancet Neurol. 2016;15(12):1257-72. https://doi.org/1 0.1016/S1474-4422(16)30230-7.

4. Grayson M. Parkinson's disease. Nature. 2016;538(7626):S1. https://doi.org/1 $0.1038 / 53851$.

5. Carabotti M, Scirocco A, Maselli MA, Severi C. The gut-brain axis: interactions between enteric microbiota, central and enteric nervous systems. Ann Gastroenterol. 2015;28(2):203-9.

6. Gold A, Turkalp ZT, Munoz DG. Enteric alpha-synuclein expression is increased in Parkinson's disease but not Alzheimer's disease. Mov Disord. 2013;28(2):237-40. https://doi.org/10.1002/mds.25298.

7. Uemura N, Yagi H, Uemura MT, Hatanaka Y, Yamakado H, Takahashi R. Inoculation of alpha-synuclein preformed fibrils into the mouse gastrointestinal tract induces Lewy body-like aggregates in the brainstem via the vagus nerve. Mol Neurodegener. 2018;13(1):21. https://doi.org/10.11 86/s13024-018-0257-5.

8. Brody H. Colorectal cancer. Nature. 2015;521(7551):S1. https://doi.org/10.103 8/521S1a.

9. Torre LA, Bray F, Siegel RL, Ferlay J, Lortet-Tieulent J, Jemal A. Global cancer statistics, 2012. CA Cancer J Clin. 2015;65(2):87-108. https://doi.org/10.3322/ caac. 21262.

10. Obuch JC, Ahnen DJ. Colorectal Cancer: genetics is changing everything. Gastroenterol Clin N Am. 2016;45(3):459-76. https://doi.org/10.1016/j.gtc.201 6.04.005.

11. Elinav E, Garrett WS, Trinchieri G, Wargo J. The cancer microbiome. Nat Rev Cancer. 2019;19(7):371-6. https://doi.org/10.1038/s41568-019-0155-3.

12. Xie X, Luo X, Xie M. Association between Parkinson's disease and risk of colorectal cancer. Parkinsonism Relat Disord. 2017;35:42-7. https://doi.org/1 0.1016/j.parkreldis.2016.11.011.
13. Zhang P, Liu B. Association between Parkinson's disease and risk of Cancer: a PRISMA-compliant Meta-analysis. ACS Chem Neurosci. 2019;10(10):4430-9. https://doi.org/10.1021/acschemneuro.9b00498.

14. Sun LM, Liang JA, Chang SN, Sung FC, Muo CH, Kao CH. Analysis of Parkinson's disease and subsequent cancer risk in Taiwan: a nationwide population-based cohort study. Neuroepidemiology. 2011;37(2):114-9. https://doi.org/10.1159/000331489.

15. Lin PY, Chang SN, Hsiao TH, Huang BT, Lin CH, Yang PC. Association between Parkinson disease and risk of Cancer in Taiwan. JAMA Oncol. 2015; 1(5):633-40. https://doi.org/10.1001/jamaoncol.2015.1752.

16. Moher D, Liberati A, Tetzlaff J, Altman DG. Preferred reporting items for systematic reviews and meta-analyses: the PRISMA statement. PLoS Med. 2009;6(7):e1000097. https://doi.org/10.1371/journal.pmed.1000097.

17. Stang A. Critical evaluation of the Newcastle-Ottawa scale for the assessment of the quality of nonrandomized studies in meta-analyses. Eur J Epidemiol. 2010;25(9):603-5. https://doi.org/10.1007/s10654-010-9491-z.

18. Higgins JP, Thompson SG, Deeks JJ, Altman DG. Measuring inconsistency in meta-analyses. Bmj. 2003;327(7414):557-60. https://doi.org/10.1136/bmj.327. 7414.557.

19. DerSimonian R, Laird N. Meta-analysis in clinical trials revisited. Contemp Clin Trials. 2015:45(Pt A):139-45.

20. Egger M, Davey Smith G, Schneider M, Minder C. Bias in meta-analysis detected by a simple, graphical test. Bmj. 1997;315(7109):629-34. https://doi. org/10.1136/bmj.315.7109.629.

21. Olsen JH, Friis S, Frederiksen K, McLaughlin JK, Mellemkjaer L, Møller H. Atypical cancer pattern in patients with Parkinson's disease. Br J Cancer. 2005;92(1):201-5. https://doi.org/10.1038/sj.bjc.6602279.

22. Fois AF, Wotton CJ, Yeates D, Turner MR, Goldacre MJ. Cancer in patients with motor neuron disease, multiple sclerosis and Parkinson's disease: record linkage studies. J Neurol Neurosurg Psychiatry. 2010;81(2):215-21. https://doi.org/10.1136/jnnp.2009.175463.

23. Becker C, Brobert GP, Johansson S, Jick SS, Meier CR. Cancer risk in association with Parkinson disease: a population-based study. Parkinsonism Relat Disord. 2010;16(3):186-90. https://doi.org/10.1016/j.parkreldis.2009.11. 005.

24. Rugbjerg K, Friis S, Lassen CF, Ritz B, Olsen JH. Malignant melanoma, breast cancer and other cancers in patients with Parkinson's disease. Int J Cancer. 2012;131(8):1904-11. https://doi.org/10.1002/ijc.27443.

25. Ong EL, Goldacre R, Goldacre M. Differential risks of cancer types in people with Parkinson's disease: a national record-linkage study. Eur J Cancer. 2014; 50(14):2456-62. https://doi.org/10.1016/j.ejca.2014.06.018.

26. Wirdefeldt K, Weibull CE, Chen H, Kamel F, Lundholm C, Fang F, et al. Parkinson's disease and cancer: a register-based family study. Am J Epidemiol. 2014;179(1):85-94. https://doi.org/10.1093/aje/kwt232.

27. Boursi B, Mamtani R, Haynes K, Yang YX. Parkinson's disease and colorectal cancer risk-a nested case control study. Cancer Epidemiol. 2016;43:9-14. https://doi.org/10.1016/j.canep.2016.05.007.

28. Guttman M, Slaughter PM, Theriault ME, DeBoer DP, Naylor CD. Parkinsonism in Ontario: comorbidity associated with hospitalization in a large cohort. Mov Disord. 2004;19(1):49-53. https://doi.org/10.1002/mds.10648.

29. Powers KM, Smith-Weller T, Franklin GM, Longstreth WT Jr, Swanson PD, Checkoway H. Diabetes, smoking, and other medical conditions in relation to Parkinson's disease risk. Parkinsonism Relat Disord. 2006;12(3):185-9. https://doi.org/10.1016/j.parkreldis.2005.09.004.

30. Driver JA, Logroscino G, Buring JE, Gaziano JM, Kurth T. A prospective cohort study of cancer incidence following the diagnosis of Parkinson's disease. Cancer Epidemiol Biomark Prev. 2007;16(6):1260-5. https://doi.org/1 0.1158/1055-9965.EPI-07-0038.

31. Lo RY, Tanner CM, Van Den Eeden SK, Albers KB, Leimpeter AD, Nelson LM. Comorbid cancer in Parkinson's disease. Mov Disord. 2010;25(12):1809-17. https://doi.org/10.1002/mds.23246.

32. Freedman DM, Pfeiffer RM. Associations between Parkinson disease and Cancer in US Asian Americans. JAMA Oncol. 2016;2(8):1093-4. https://doi. org/10.1001/jamaoncol.2016.0729.

33. Freedman DM, Wu J, Chen H, Engels EA, Enewold LR, Freedman ND, et al. Associations between cancer and Parkinson's disease in U.S. elderly adults. Int J Epidemiol. 2016;45(3):741-51. https://doi.org/10.1093/ije/dyw016.

34. Peretz C, Gurel R, Rozani V, Gurevich T, El-Ad B, Tsamir J, et al. Cancer incidence among Parkinson's disease patients in a 10-yrs time-window around disease onset: a large-scale cohort study. Parkinsonism Relat Disord. 2016;28:68-72. https://doi.org/10.1016/j.parkreldis.2016.04.028. 
35. Park JH, Kim DH, Park YG, Kwon DY, Choi M, Jung JH, et al. Cancer risk in patients with Parkinson's disease in South Korea: a nationwide, populationbased cohort study. Eur J Cancer. 2019;117:5-13. https://doi.org/10.1016/j. ejca.2019.04.033.

36. Schernhammer E, Chen H, Ritz B. Circulating melatonin levels: possible link between Parkinson's disease and cancer risk? Cancer Causes Control. 2006; 17(4):577-82. https://doi.org/10.1007/s10552-005-9002-9.

37. Sarkar C, Chakroborty D, Dasgupta PS, Basu S. Dopamine is a safe antiangiogenic drug which can also prevent 5-fluorouracil induced neutropenia. Int J Cancer. 2015;137(3):744-9. https://doi.org/10.1002/ijc.2 9414.

38. Hernan MA, Takkouche B, Caamano-Isorna F, Gestal-Otero JJ. A metaanalysis of coffee drinking, cigarette smoking, and the risk of Parkinson's disease. Ann Neurol. 2002;52(3):276-84. https://doi.org/10.1002/ana.10277.

39. Carstensen B, Jorgensen ME, Friis $\mathrm{S}$. The epidemiology of diabetes and cancer. Curr Diab Rep. 2014;14(10):535. https://doi.org/10.1007/s1 1892-0140535-8.

40. Keshavarzian A, Green SJ, Engen PA, Voigt RM, Naqib A, Forsyth CB, et al. Colonic bacterial composition in Parkinson's disease. Mov Disord. 2015; 30(10):1351-60. https://doi.org/10.1002/mds.26307.

41. Hyer ML, Milhollen MA, Ciavarri J, Fleming P, Traore T, Sappal D, et al. A small-molecule inhibitor of the ubiquitin activating enzyme for cancer treatment. Nat Med. 2018;24(2):186-93. https://doi.org/10.1038/nm.4474.

42. Sherman MY, Goldberg AL. Cellular defenses against unfolded proteins: a cell biologist thinks about neurodegenerative diseases. Neuron. 2001;29(1): 15-32. https://doi.org/10.1016/S0896-6273(01)00177-5.

43. Manasanch EE, Orlowski RZ. Proteasome inhibitors in cancer therapy. Nat Rev Clin Oncol. 2017;14(7):417-33. https://doi.org/10.1038/nrclinonc.2016.206.

44. Bahrami A, Khazaei M, Hasanzadeh M, ShahidSales S, Joudi Mashhad M, Farazestanian $\mathrm{M}$, et al. Therapeutic potential of targeting PI3K/AKT pathway in treatment of colorectal Cancer: rational and Progress. J Cell Biochem. 2018;119(3):2460-9. https://doi.org/10.1002/jcb.25950.

45. Leikas JV, Kohtala S, Theilmann W, Jalkanen AJ, Forsberg MM, Rantamäki T. Brief isoflurane anesthesia regulates striatal AKT-GSK3 $\beta$ signaling and ameliorates motor deficits in a rat model of early-stage Parkinson's disease. J Neurochem. 2017;142(3):456-63. https://doi.org/10.1111/jnc.14066.

\section{Publisher's Note}

Springer Nature remains neutral with regard to jurisdictional claims in published maps and institutional affiliations.

Ready to submit your research? Choose BMC and benefit from:

- fast, convenient online submission

- thorough peer review by experienced researchers in your field

- rapid publication on acceptance

- support for research data, including large and complex data types

- gold Open Access which fosters wider collaboration and increased citations

- maximum visibility for your research: over $100 \mathrm{M}$ website views per year

At $\mathrm{BMC}$, research is always in progress.

Learn more biomedcentral.com/submissions 